\title{
PERTUMBUHAN BIBIT AREN (Arenga pinnata Merr) PADA MEDIA TANAH ULTISOL DIPERSEMAIAN
}

\author{
(Growth of Arenga pinnata Merr on Ultisol at the Nursery)
}

\author{
Janting, Abdurrani Muin, Burhanuddin \\ Fakultas Kehutanan Universitas Tanjungpura. Jln Imam Bonjol Pontianak 78124 \\ Email : jantingkh@gmail.com
}

\begin{abstract}
Arenga pinnata Merr is a multipurpose trees species that has long been known to produce industrial materials. Based on the utilization of Arenga pinnata Merr is not only limited to the food alone but also used as a raw material for industrial and land conservation. Arenga pinnata Merr has prospect good to be developed in the tree crop plantations. Arenga pinnata Merr cultivation activities require good quality seeds. Currently Arenga pinnata Merr still growing naturally in the forest. Exploitation by the farmers during this time in the form of Arenga pinnata Merr exploitation of the forest without cultivation. There are concerns Arenga pinnata Merr that grows in nature will be destroyed. The purpose of this research to study the effect of a doses of organic fertilizer and dolomite lime on the growth of Arenga pinnata Merr in the nursery. The study used an experimental method with a completely randomized design factorial models. The study consisted of two factors: factors of organic fertilizer and lime dolomite with five repetitions with a number of plant samples as many as 100 plants. The measured parameters include length midrib, stem diameter and stem height were analyzed using SAS IX. The research proves that organic fertilizer dose of $300 \mathrm{~g}$ and $35 \mathrm{~g}$ dolomite lime can increase the growth of palm in the nursery.
\end{abstract}

Keywords: Arenga pinnata Merr, fertilizer, lime, organic.

\section{PENDAHULUAN}

Tanaman aren (Arenga pinnata Merr) merupakan salah satu tanaman non kayu yang multi manfaat. Menurut Yatni dan Syahidah (2008) pemanfaatan sumberdaya hutan secara multi fungsi lebih menjamin kelestarian hutan karena hutan tidak hanya berfungsi sebagai penghasil kayu, produk bukan kayu seperti aren merupakan sumber bahan pangan bagi penduduk, sebagai penghasil pakan ternak, penghasil buahbuahan dan tanaman semusim serta dapat memberi manfaat jasa lingkungan dan jasa sosial. Tanaman aren sebagai bahan yang hidup, memiliki kemampuan fungsi hidroorologis yang tinggi sehingga sangat sesuai untuk tanaman konservasi
(Allorerung 2007). Selain sebagai tanaman konservasi aren digunakan sebagai penanggulangan degradasi dan reboisasi lahan yang rusak, hal ini dikarenakan aren memiliki perakaran yang kuat menahan erosi dalam mengurangi kecepatan aliran permukaan, memperbesar kapasitas infiltrasi tanah dan meningkatkan aktivitas biota tanah, memiliki tajuk yang lebat untuk menghalangi terpaan langsung butiran air hujan, pelindung angin, serta toleran terhadap berbagai jenis tanaman campuran serta tidak memerlukan penanganan yang intensif dalam pemeliharaan Alam dan Djafar (2004) dalam (Maliangkay, 2011). 
Aren ternyata dapat menghasilkan 60 jenis produk bernilai ekonomi dan beberapa produk berpotensi untuk diekspor, bahkan aren berperan sebagai penyuplai energi dan untuk pelestarian lingkungan hidup (Maliangkay, 2012). Hasil utama dari tanaman aren adalah nira dengan jenis olahannya berupa gula merah, gula semut, alkohol. Peluang pengembangan tanaman ini selain ketersediaan teknologi yang ada, mudah beradabtasi pada berbagai tipe tanah diseluruh Indonesia termasuk lahan kritis, alang-alang dan sebagai tanaman konservasi hutan. Menurt Widodo (2008), menyatakan bahwa pupuk organik kotoran ayam dengan pemberian sedikit kapur dolomit dapat memberikan pengaruh yang baik terhadap pertumbuhan bibit aren dan juga akan memperbaiki sifat kimia dan fisik tanah yang diusahakan.

Manfaat pupuk organik dalam tanah sebagai suplai hara makro dan mikro, meningkatkan kandungan bahan organik tanah sehingga memperbaiki kemampuan tanah menahan air, menambah porosistas dan meningkatkan kegiatan jasad renik dalam tanah. Menurut Tisdale dan Nelson (1975) dalam Nurmansyah dan Burhanuddin (2010) menyatakan bahwa pengapuran dapat meningkatkan $\mathrm{pH}$ tanah, menekan kelarutan $\mathrm{Al}$, dan $\mathrm{Fe}$ (yang biasa tinggi pada tanah-tanah mineral masam seperti ultisol) dan akibatnya serapan hara akan meningkat, sehingga kondisi tanah seperti ini kurang menguntungkan bagi bibit. Faktor pembatas pada sifat fisik tanah yaitu : pada tekstur debu, liat berpasir. Struktur dengan konsistensinya keras dan permeabilitasnya rendah.
Umumnya tanah di Kalimantan Barat bersifat asam atau ( $\mathrm{pH}$ rendah), salah satu adalah tanah ultisol. Sebagai media semai, tanah ultisol memiliki beberapa faktor pembatas pada sifat kimia tanah yaitu: $\mathrm{pH}$ rendah, kelarutan $\mathrm{Al}, \mathrm{Mn}$, Fe relatif tinggi, kandungan $\mathrm{Ca}, \mathrm{Mg}$, Mo relatif rendah dan kandungan $\mathrm{N}, \mathrm{P}$ dan $\mathrm{S}$ kurang karena dekomposisi berlangsung sangat lambat.

Kondisi pertumbuhan aren (Arenga pinnata Merr) pada tingkat semai sangat menentukan keberhasilan penanaman dilapangan. Maka dari itu upaya untuk meningkatkan pertumbuhan bibit aren khususnya pada tahap persemaian, perlu penambahan energi dari luar yaitu pemberian pupuk organik sehingga ketersediaan unsur hara yang diperlukan tanaman cukup dan seimbang.

Penelitian ini bertujuan untuk mengetahui campuran pupuk organik kotoran ayam dan kapur dolomit pada media tanah ultisol dopersemaian. Manfaat penelitian ini untuk memberikan masukkan atau informasi dalam melakukan pemupukan dengan pupuk organik kotoran ayam dan kapur dolomit pada tanah ultisol sebagai media tumbuh dipersemaian yang memenuhi syarat untuk pertumbuhan bibit aren yang berkualitas baik.

\section{METODOLOGI PENELITIAN}

Penelitian ini dilaksanakan di persemaian kebun karet TBM, Desa Urang Unsa, Kecamatan Putussibau Selatan Kabupaten Kapuas Hulu. Lamanya penelitian dilakukan selama 5 bulan mulai dari bulan Mei sampai dengan Oktober 2014. Alat yang digunakan dalam penelitian adalah Cangkul, Timbangan, Alat tulis menuluis, Ayakan dari kawat, 
Karung goni, Kamera, Gunting, Mistar, Kalkulator, Caliper atau Jangka sorong, Sprayer, Label, Lidi dan Staples. Bahan penelitian yang digunakan adalah: Bibit aren (Arenga pinnata Merr), Tanah ultisol, Pupuk organik Kotoran ayam, Kapur dolomit, Polybag ukuran 25x25 cm.

\section{Persiapan Media Tanam}

Tahap awal penelitian ini adalah persesiapan media, Media yang digunakan adalah tanah ultisol, pupuk organik kotoran ayam yang telah kering, diambil dari kandang ternak ayam di Mufa Kecamatan Putussibau Utara, Kapur dolomit dari kios pertanian.

Kemudian tanah ultisol dan pupuk kotoran ayam dianalisis terlebih dahulu di Laboratorium Kimia dan kesuburan tanah di Fakultas Pertanian Universitas Tanjungpura. Setelah itu tanah dikeringanginkan dan diayak. Selanjutnya hasil ayakan tanah ultisol di campur dengan kotoran ayam dan kapur dolomit berdasarkan masing-masing perlakuan yang ditentukan sebagai berikut $2 \mathrm{~kg}: 200$ g: 0 g, $2 \mathrm{~kg}: 300 \mathrm{~g}: 25 \mathrm{~g}, 2 \mathrm{~kg}: 400 \mathrm{~g}: 35$ g, $2 \mathrm{~kg}: 500 \mathrm{~g}: 45 \mathrm{~g}$. Hasil campuran kemudian dimasukkan ke dalam polybag yang sudah dipersiapkan sebelumnya. Bibit aren dipindahkan 2 Minggu setelah percampuran media tersebut. Tahap kedua penyapihan bibit dilakukan dengan memilih bibit yang sehat, tinggi apokol (bibit aren belum keluar akar) $7 \mathrm{~cm}$ dan berdiameter yang relatif seragam dengan umur bibit 2 bulan. Bibit aren tersebut dimasukkan ke dalam polybag yang telah diisi dengan campuran tanah ultisol, kapur dolomit dan pupuk organik berupa kotoran ayam. Masing-masing polybag ditanam satu bibit aren, kemudian polybag tersebut ditempatkan dan disusun didalam bedengan persemaian. Tahap ketiga pemupukan dilakukan satu kali pada saat perlakuan tahap awal saja yang telah ditentukan. Pupuk organik yang digunakan dalam penelitian ini dianalisis terlebih dahulu di Laboratorium Kimia dan Kesuburan Tanah Faperta Universitas Tanjungpura, kemudian pupuk organik yang sudah matang atau kering dihancurkan dalam karung dan baru dicampur dengan tanah bersamaan dengan kapur dolomit. Tahap keempat pemeliharaan, pemeliharaan ini meliputi penyiraman, penyiangan dan pengendalian hama. Penyiraman tanaman dilakukan dua kali sehari yaitu pagi dan sore disesuaikan dengan kondisi cuaca setempat. Penyiangan dilakukan untuk membersihkan gulma yang tumbuh di dalam dan luar polybag.

Data variabel penelitian diperoleh melalui pengukuran panjang pelepah daun, diameter batang dan tinggi batang bibit. Dan data penunjang penelitian diperoleh melalui suhu udara, kelembaban udara, dan curah hujan. Analisis tanah dan kotoran ayam diperoleh dari hasil analisis Laboratorium kimia dan kesuburan tanah Fakultas Pertanian Universitas Tanjungpura.

Data yang diperoleh berupa panjang pelepah daun, diameter batang dan tinggi batang bibit dengan analisis sidik ragam (uji F) menggunakan program SAS.13. Jika terdapat perbedaan nyata pada uji $\mathrm{F}$ dengan taraf 5\% maka akan dilanjutkan dengan uji Beda Nyata Jujur (BNJ) untuk menentukan perlakuan terbaik. 


\section{HASIL DAN PEMBAHASAN}

Berdasarkan penelitian yang dilakukan dengan mengamati pertumbuhan bibit aren (Arenga pinnata Merr) dengan pemberian pupuk organik kotoran ayam dan kapur dolomit pada tanah ultisol dipersemaian dengan berbagai komposisi terhadap 3 parameter yang diukur yaitu : panjang pelepah daun, diameter batang dan tinggi batang bibit. Hasil rekapitulasi Sidik Ragam untuk parameter panjang pelepah, diameter batang dan tinggi batang bibit terdapat pada Tabel 1.

Tabel 1. Hasil Sidik Ragam Pengaruh Pemberian Pupuk dan Kapur Terhadap pertumbuhan panjang pelepah, diameter batang dan tinggi batang bibit aren. (effect of lime and fertilizer for long midrib, diameter and stem height A. pinnata).

\begin{tabular}{lccc}
\hline Sumber Keragaman & Panjang pelepah & Diameter & Tinggi \\
\hline Perlakuan & $* *$ & $* *$ & $* *$ \\
Galat & & & \\
\hline
\end{tabular}

Keterangan : $* *=$ Berpengaruh Sangat Nyata

Panjang pelepah bibit (cm)

Untuk mengetahui lebih jelas pengaruh pemberian Pupuk dan Kapur Terhadap pertumbuhan panjang pelepah daun aren secara visual dapat dilihat pada Gambar 1 .

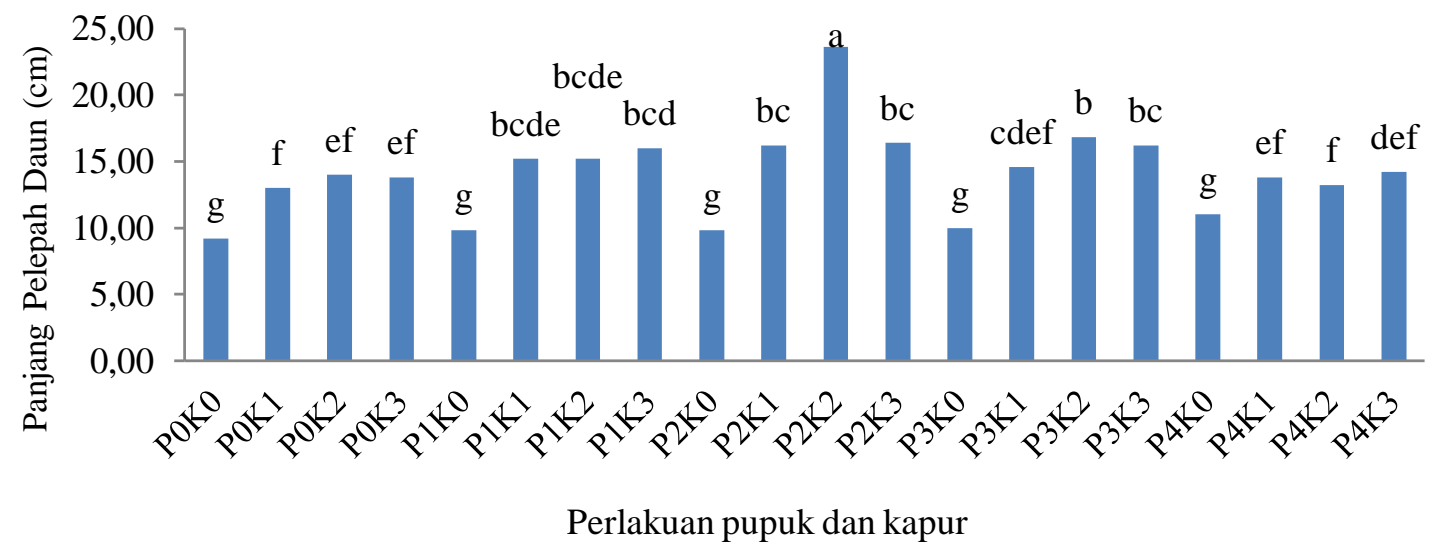

Gambar 1. Pengaruh pemberian Pupuk dan Kapur Terhadap pertumbuhan panjang pelepah daun bibit aren (Effect of lime and fertilizer for long midrib A.pinnata)

Keterangan :

P0K0 = tanpa pupuk dan kapur

$\mathrm{P} 0 \mathrm{~K} 2$ = tanpa pupuk, kapur $35 \mathrm{~g} /$ polybag

$\mathrm{P} 1 \mathrm{~K} 0$ = pupuk $200 \mathrm{~g}$, tanpa kapur/polybag

$\mathrm{P} 1 \mathrm{~K} 2=$ pupuk $200 \mathrm{~g}$, kapur $35 \mathrm{~g} /$ polybag

$\mathrm{P} 2 \mathrm{~K} 0=$ pupuk $300 \mathrm{~g}$, tanpa kapur/polybag

P2K2 = pupuk $300 \mathrm{~g}$, kapur $35 \mathrm{~g} /$ polybag

$\mathrm{P} 3 \mathrm{~K} 0=$ pupuk $400 \mathrm{~g}$, tanpa kapur/polybag

$\mathrm{P} 3 \mathrm{~K} 2=$ pupuk $400 \mathrm{~g}$, kapur $35 \mathrm{~g} /$ polybag

$\mathrm{P} 4 \mathrm{~K} 0=$ pupuk $500 \mathrm{~g}$, tanpa kapur/polybag

$\mathrm{P} 4 \mathrm{~K} 2=$ pupuk $500 \mathrm{~g}$, kapur $35 \mathrm{~g} /$ polybag
P0K1 = tanpa pupuk, kapur $25 \mathrm{~g} /$ polybag

P0K3 = tanpa pupuk, kapur $45 \mathrm{~g} /$ polybag

$\mathrm{P} 1 \mathrm{~K} 1=$ pupuk $200 \mathrm{~g}$, kapur $25 \mathrm{~g} /$ polybag

$\mathrm{P} 1 \mathrm{~K} 3=$ pupuk $200 \mathrm{~g}$, kapur $45 \mathrm{~g} /$ polybag

$\mathrm{P} 2 \mathrm{~K} 1=$ pupuk $300 \mathrm{~g}$, kapur $25 \mathrm{~g} /$ polybag

$\mathrm{P} 2 \mathrm{~K} 3=$ pupuk $300 \mathrm{~g}$, kapur $45 \mathrm{~g} /$ polybag

$\mathrm{P} 3 \mathrm{~K} 1=$ pupuk $400 \mathrm{~g}$, kapur $25 \mathrm{~g} /$ polybag

$\mathrm{P} 3 \mathrm{~K} 3=$ pupuk $400 \mathrm{~g}$, kapur $45 \mathrm{~g} /$ polybag

$\mathrm{P} 4 \mathrm{~K} 1=$ pupuk $500 \mathrm{~g}$, kapur $25 \mathrm{~g} /$ polybag

$\mathrm{P} 4 \mathrm{~K} 3=$ pupuk $500 \mathrm{~g}$, kapur $45 \mathrm{~g} /$ polybag 
Huruf yang sama pada histogram menunjukkan perbedaan yang tidak nyata berdasarkan uji beda nyata jujur. Pada histogram Gambar 1. Menunujkkan pengaruh pemberian Pupuk organik kotoran ayam dan Kapur dolomit Terhadap pertumbuhan panjang pelepah yang diberi perlakuan P2K2 yaitu campuran Tanah Ultisol + Pupuk organik + Kapur dolomit : $2 \mathrm{~kg}: 300 \mathrm{~g}$ :
$35 \mathrm{~g} /$ polybag berbeda sangat nyata bila dibandingan dengan kontrol dan tanah ultisol + pupuk kotoran ayam $2 \mathrm{~kg}: 200$ g/ polybag. Sedanglan perlakuan $\mathrm{P} 3 \mathrm{~K} 2$ tidak berbeda nyata dengan perlakuan P2K3, P2K1 dan P1K3.

\section{Diameter batang bibit (mm).}

Untuk menunjukkan perbedaan pertambahan diameter batang bibit aren dapat dilihat pada Gambar 2.

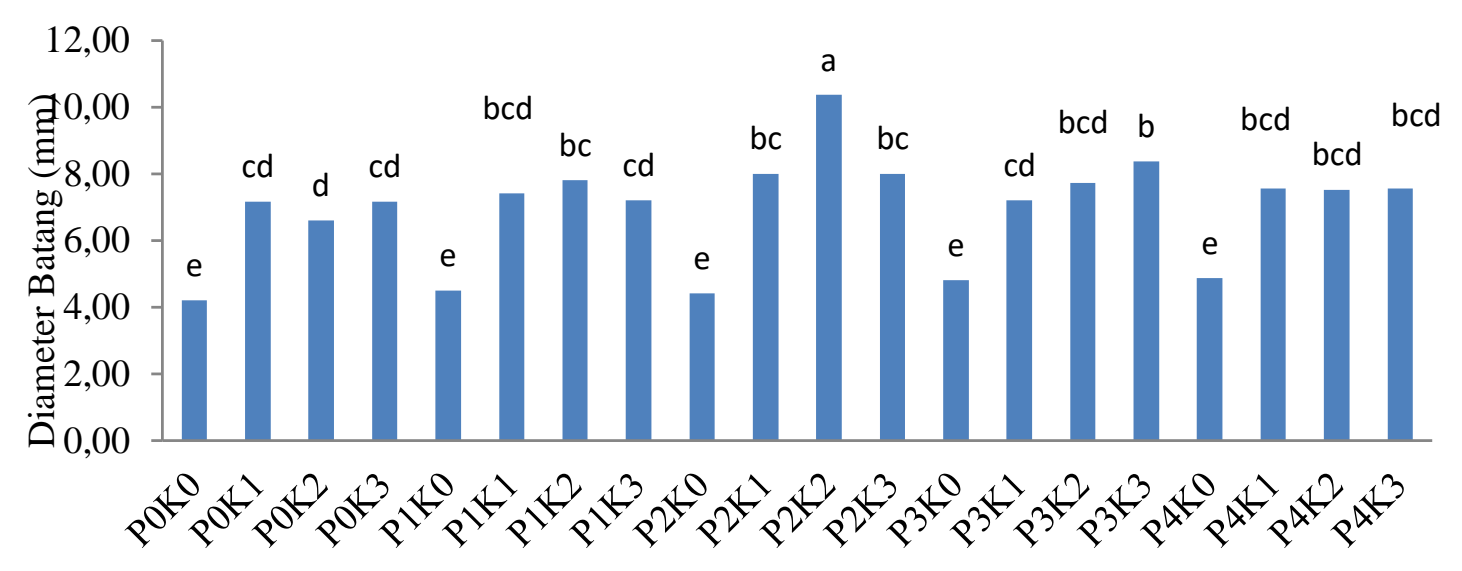

Pengaruh pupuk dan kapur

Gambar 2. Pertambahan diameter batang bibit aren (Growth of diameter A.pinnata) Keterangan :

P0K0 = Tanpa pupuk dan kapur

P0K1 = tanpa pupuk, kapur $25 \mathrm{~g} /$ polybag

$\mathrm{P} 0 \mathrm{~K} 2$ = tanpa pupuk, kapur $35 \mathrm{~g} /$ polybag

P0K3 = tanpa pupuk, kapur $45 \mathrm{~g} /$ polybag

$\mathrm{P} 1 \mathrm{~K} 0=$ pupuk $200 \mathrm{~g}$, tanpa kapur /polybag

$\mathrm{P} 1 \mathrm{~K} 1=$ pupuk $200 \mathrm{~g}$ kapur $25 \mathrm{~g} /$ polybag

$\mathrm{P} 1 \mathrm{~K} 2=$ pupuk $200 \mathrm{~g}$, kapur $35 \mathrm{~g} /$ polybag

$\mathrm{P} 2 \mathrm{~K} 0=$ pupuk $300 \mathrm{~g}$, tanpa kapur /polybag

$\mathrm{P} 1 \mathrm{~K} 3=$ pupuk $200 \mathrm{~g}$ kapur $45 \mathrm{~g} /$ polybag

$\mathrm{P} 2 \mathrm{~K} 2=$ pupuk $300 \mathrm{~g}$, kapur $35 \mathrm{~g} /$ polybag

$\mathrm{P} 2 \mathrm{~K} 1=$ pupuk $300 \mathrm{~g}$ kapur $25 \mathrm{~g} /$ polybag

$\mathrm{P} 3 \mathrm{~K} 0=$ pupuk $400 \mathrm{~g}$, tanpa kapur / polybag

$\mathrm{P} 2 \mathrm{~K} 3=$ pupuk $300 \mathrm{~g}$ kapur $45 \mathrm{~g} /$ polybag

P3K2 = pupuk $400 \mathrm{~g}$, kapur $35 \mathrm{~g} /$ polybag

$\mathrm{P} 3 \mathrm{~K} 1=$ pupuk $400 \mathrm{~g}$ kapur $25 \mathrm{~g} /$ polybag

$\mathrm{P} 4 \mathrm{~K} 0=$ pupuk $500 \mathrm{~g}$, tanpa kapur / polybag $\mathrm{P} 4 \mathrm{~K} 1=$ pupuk $500 \mathrm{~g}$ kapur $25 \mathrm{~g} /$ polybag

$\mathrm{K} 4 \mathrm{~K} 2=$ pupuk $500 \mathrm{~g}$, kapur $35 \mathrm{~g} /$ polybag $\mathrm{K} 4 \mathrm{~K} 3=$ pupuk $500 \mathrm{~g}$ kapur $45 \mathrm{~g} /$ polybag

Huruf yang sama pada histogram menunjukkan perbedaan yang tidak nyata berdasarkan uji beda nyata jujur. Pada histogram Gambar 2. Pengaruh pemberian Pupuk kotoran ayam dan
Kapur dolomit terhadap pertambahan diameter batabg yang diberi perlakuan P2K2 yaitu campuran Tanah Ultisol + Pupuk organik + Kapur dolomit : $2 \mathrm{~kg}$ : $300 \mathrm{~g}: 35 \mathrm{~g} /$ polybag berbeda sangat 
nyata bila dibandingan dengan kontrol. tetapi berbeda nyata dengan perlakuan P3K3 dan P4K3.
Untuk mengetahui perbedaan pertambahan tinggi batang bibit aren dapat dilihat pada Gambar 3.

\section{Tinggi batang bibit (cm)}

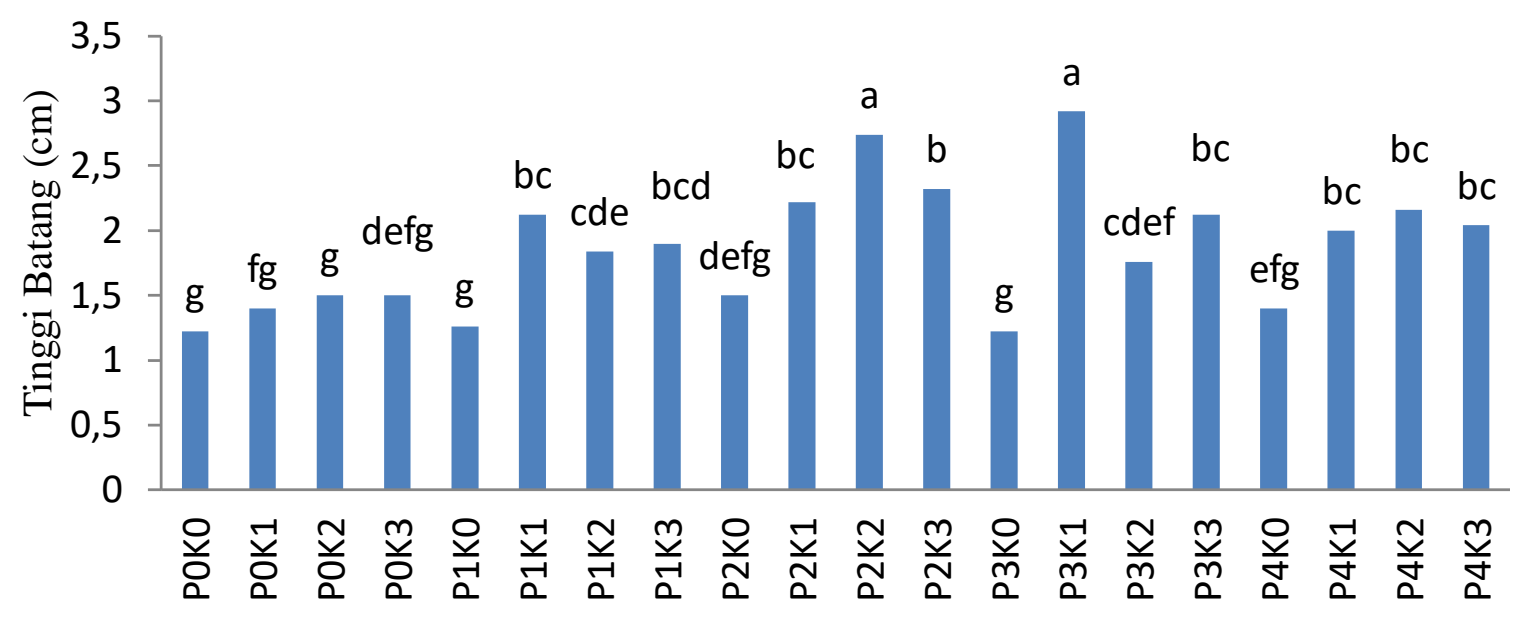

Perlakuan pupuk dan kapur

Gambar 3. Pertambahan tinggi batang bibit aren (Growth of stem height A.pinnata)

Keterangan :

P0K0 = Tanpa pupuk dan kapur

$\mathrm{P} 0 \mathrm{~K} 1$ = tanpa pupuk, kapur $25 \mathrm{~g} /$ polybag

P0K2 = tanpa pupuk, kapur $35 \mathrm{~g} /$ polybag $\mathrm{P} 0 \mathrm{~K} 3$ = tanpa pupuk, kapur $45 \mathrm{~g} /$ polybag

$\mathrm{P} 1 \mathrm{~K} 0=$ pupuk $200 \mathrm{~g}$ tanpa kapur/polybag $\mathrm{P} 1 \mathrm{~K} 1$ = pupuk $200 \mathrm{~g}$ kapur $25 \mathrm{~g} /$ polybag

$\mathrm{P} 1 \mathrm{~K} 2=$ pupuk $200 \mathrm{~g}$ kapur $35 \mathrm{~g} /$ polybag $\mathrm{P} 1 \mathrm{~K} 3=$ pupuk $200 \mathrm{~g}$ kapur $45 \mathrm{~g} /$ polybag

$\mathrm{P} 2 \mathrm{~K} 0=$ pupuk $300 \mathrm{~g}$ tanpa $\mathrm{kapur} /$ polybag $\mathrm{P} 2 \mathrm{~K} 1=$ pupuk $300 \mathrm{~g}$ kapur $25 \mathrm{~g} /$ polybag

$\mathrm{P} 2 \mathrm{~K} 2=$ pupuk $300 \mathrm{~g}$ kapur $35 \mathrm{~g} /$ polybag $\mathrm{P} 2 \mathrm{~K} 3=$ pupuk $300 \mathrm{~g}$ kapur $45 \mathrm{~g} /$ polybag

$\mathrm{P} 3 \mathrm{~K} 0=$ pupuk $400 \mathrm{~g}$ tanpa $\mathrm{kapur} /$ polybag $\mathrm{P} 3 \mathrm{~K} 1=$ pupuk $400 \mathrm{~g}$ kapur $25 \mathrm{~g} /$ polybag

$\mathrm{P} 3 \mathrm{~K} 2=$ pupuk $400 \mathrm{~g}$ kapur $35 \mathrm{~g} /$ polybag $\mathrm{P} 3 \mathrm{~K} 3=$ pupuk $400 \mathrm{~g}$ kapur $45 \mathrm{~g} /$ polybag

$\mathrm{P} 4 \mathrm{~K} 0=$ pupuk $500 \mathrm{~g}$ tanpa kapur /polybag $\mathrm{P} 4 \mathrm{~K} 1=$ pupuk $500 \mathrm{~g}$ kapur $25 \mathrm{~g} /$ polybag

$\mathrm{P} 4 \mathrm{~K} 2$ = pupuk $500 \mathrm{~g}$ kapur $35 \mathrm{~g} /$ polybag $\mathrm{P} 4 \mathrm{~K} 3=$ pupuk $500 \mathrm{~g}$ kapur $45 \mathrm{~g} /$ polybag

Huruf yang sama pada histogram menunjukkan perbedaan yang tidak nyata berdasarkan uji beda nyata jujur.

Pada histogram Gambar 3. Menunjukkan pertambahan tinggi batang yang diberi perlakuan P2K2 yaitu campuran tanah ultisol + pupuk organik kotoran ayam + kapur dolomit: $300 \mathrm{~g}$ : $35 \mathrm{~g} /$ polybag berbeda sangat nyata dibandingkan dengan kontrol.
Berdasarkan hasil perhitungan sidik ragam dan uji lanjut untuk panjang pelepah, diameter batang dan tinggi batang bibit aren: $300 \mathrm{~g}: 35 \mathrm{~g} /$ polybag merupakan dosis yang optimum dalam meningkatkan pertumbuhan bibit aren.

Jika dilihat dari grafik panjang pelepah daun, diameter batang dan tinggi 
batang menunjukkan bahwa perlakuan campuran tanah ultisol + kotoran ayam + kapur dolomit: $300 \mathrm{~g}$ : 35 g menunjukkan nilai rerata yang tertinggi $61,01,59,45$, dan 55,47. Jika dibandingkan dengan perlakuan lainnya terutama untuk perlakuan kontrol (tanah ultisol murni) menunjukkan pertambahan yang paling kecil, hal ini disebabkan didalam tanah ultisol tidak terkandung unsur-unsur hara yang sesuai kebutuhan bagi pertumbuhan bibit aren. Panjang pelepah daun merupakan salah satu parameter yang penting dalam pertumbuhan bibit karena pada panjang pelepah daun merupakan dasar tempat daun tumbuh dan daun terdapat stomata yang berfungsi mengalirkan $\mathrm{CO}_{2}$ digunakan sebagai proses fotosintesis tanaman. Dalam hal ini pertumbuhan panjang pelepah yang dihasilkan berpengaruh nyata disebabkan pertambahan panjang pelepah daun yang banyak karena semakin bertambahnya panjang pelepah daun berpengaruh juga terhadap bertambahnya jumlah daun maka bidang fotosintesisnya semakin luas sehingga pertumbuhan semakin baik Feskaharny 2009 dalam (Sadari dan Burhanudin, 2013).

Pupuk kandang kotoran ayam mengandung unsur hara makro $(\mathrm{N}, \mathrm{P}, \mathrm{K})$ yang cukup tinggi senhingga mampu meningkatkan kesuburan dengan memperbaiki sifat fisik, kimia dan biologi tanah serta pertumbuhan perakaran tanaman akan menjadi lebih baiksehingga dapat meningkatkan absorbsi unsur hara oleh akar (Hakim et al, 1986).
Pemberian pupuk kotoran ayam pada berbagai perbandingan ( $\mathrm{P}$ dan $\mathrm{K}$ ) dengan tanah ultisol menunjukkan bahwa perlakuan P2K2 yaitu campuran tanah ultisol + kotoran ayam + kapur dolomit : $300 \mathrm{~g}: 35 \mathrm{~g}$ /polybag merupakan perbandingan yang optimum dalam meningkatkan pertumbuhan bibit aren ini dapat dilihat dari nilai rerata pertambahan panjang pelepah daun, diameter batang dan tinggi batang yang tertinggi.

Hal ini disebabkan unsur hara yang diserap oleh bibit aren sesuai dan seimbang dengan kebutuhan tanaman tersebut, selain itu juga pemberian kapur dolomit dan pupuk organik ke dalam tanah dapat menurunkan dan meniadakan pengaruh $\mathrm{Al}$ terhadap pertumbuhan tanaman, memperbaiki sifat fisik, kimia dan biologi tanah. Pupuk organik mutlak diberikan pada tanah yang bereaksi masam seperti tanah ultisol. Menurut Widodo (2008) bahan organik merupakan sumber nitrogen tanah yang utama, serta berperan cukup besar dalam memperbaiki sifat fisik, kimia dan biologi tanah dan lingkungan. Dalam tanah pupuk organik akan dirombak oleh organisme menjadi humus atau bahan organik tanah. Kondisi tanah ultisol yang demikian menyebabkan aerasi tanah menjadi lebih baik sehingga kandungan oksigen di dalam tanah sesuai dengan kebutuhan bibit aren dipersemaian.

Seperti dijelaskan Hakim et al, (1986) pemberian bahan organik (kotoran ayam) ke dalam tanah maka jumlah dan aktivitas metabolik 
organisme akan meningkat dan dekomposisi bahan organik juga meningkat sehingga sangat baik dalam mendukung pertumbuhan bibit aren. Seperti ditambahkan menurut Maliangkay et al (2002), pupuk dari kotoran ayam mudah terdekomposisi dan reaksinya yang cepat larut dalam tanah sehingga unsur hara menjadi cepat tersedia bagi tanaman yang mempunyai siklus tanam pendek seperti sayuran.

Selain unsur hara yang cukup tersedia dalam media tersebut ada beberapa faktor yang mempengaruhi pertumbuhan bibit aren seperti faktor tanah, iklim dan faktor lingkungan. Faktor tanah adalah faktor yang berhubungan dengan keadaan tanah. Faktor yang berpengaruh langsung terhadap pertumbuhan tanaman dapat dikelompokan menjadi dua : pertama yang berkaitan dengan sifat fisik tanah antara lain : tekstur (susunan partikel tanah), air tanah dan temperatur tanah. Kedua sifat kimia tanah seperti unsurunsur hara, keasaman tanah $(\mathrm{pH})$ dan kemampuan tanah mempertukarkan kation (KTK) yang terkandung dalam tanah (Widodo, 2008). Menurut Sudrajat (2010) faktor-faktor mendasar yang secara langsung menyebabkan pertumbuhan yang kerdil adalah keracunan Al merupakan salah satu faktor terbesar yang menghambat pertumbuhan tanaman pada tanah masam. Gejala pertama yang tampak dari keracunan $\mathrm{Al}$ adalah sistem perakaran yang tidak berkembang (pendek dan tebal) sebagai akibat penghambatan perpanjangan sel.
Pengaruh percampuran pupuk kotoran ayam, kapur dolomit dan tanah ultisol dengan berbagai komposisi kandungan hara N,P dan $\mathrm{K}$ lebih tinggi dibanding dengan tanaman yang menggunakan tanah ultisol murni (tanpa perlakuan), hal ini dapat menyebabkan bibit aren dipersemaian tumbuh baik seperti pertumbuhan panjang pelepah daun, diameter batang dan tinggi batang bibit. Menurut Wijarnako dan Subandi (2013) pemberian kapur dapat meningkatkan ketersediaan unsur fosfor (P) dan Molibdenum (Mo). Pengapuran adalah cara untuk menaikkan $\mathrm{pH}$ tanah yang rendah, menambah unsur $\mathrm{Ca}, \mathrm{Mg}$, ketersediaan $\mathrm{P}$ dan Mo serta mengurangi keracunan yang disebabkan oleh $\mathrm{Al}, \mathrm{Fe}$, dan Mn (Santoso B, 2006). Selain itu pemberian kapur dapat meningkatkan aktivitas biologi tanah, oleh karena itu $\mathrm{pH}$ tanah perlu dinaikkan agar unsurunsur hara seperti $\mathrm{P}$ mudah diserap tanaman dan keracunan Al dapat dihindarkan (Santoso A, 2012).

Faktor iklim adalah faktor yang berhubungan dengan keadaan atmosfer yang berpengaruh langsung terhadap kehidupan tanaman seperti sinar matahari, suhu udara, kelembaban udara dan curah hujan.

Faktor lingkungan (genetik) adalah faktor yang berpengaruh tidak langsung terhadap pertumbuhan tanaman antara lain : ketinggian suatu tempat dari permukaan laut, faktor kelerengan dan faktor genetik dari benih seperti masa dormansi benih aren.

Dari beberapa kombinasi perlakuan dapat dikatakan bahwa campuran pupuk 
organik kotoran ayam, kapur dolomit dan tanah ultisol ternyata menunjukkan pertumbuhan terhadap parameter yang diamati seperti panjang pelepah daun, diameter batang dan tinggi batangan bibit lebih baik dibandingkan dengan tanaman pada media tanpa pupuk organik kotoran ayam dan kapur dolomit (kontrol), hal ini dapat dibuktikan dari semua perlakuan yang diamati.

\section{KESIMPULAN}

Pemberian pupuk organik kotoran ayam dan kapur dolomit perlakuan P2K2 tanah ultisol + pupuk organik kotoran ayam + kapur dolomit (2kg : 300g : 35g /polybag) memberikan pengaruh yang sangat nyata terhadap pertambahan panjang pelepah daun $61,01 \%$, diameter batang 59,45\%, tinggi batang bibit $55,47 \%$ terhadap kontrol bibit aren (Arenga pinnata Merr) dipersemaian. Pemberian pupuk organik dan kapur pada tanah ultisol pada perlakuan P2K2 yaitu (300 g : $35 \mathrm{~g} /$ polybag) sudah dapat memberikan hasil yang maksimal terhadap pertambahan parameter yang diamati.

Mempercepat pertumbuhan bibit aren dipersemaian yang menggunakan tanah ultisol dapat diberikan pupuk organik kotoran ayam sebanyak $300 \mathrm{~g} /$ polybag dan kapur dolomit $35 \mathrm{~g} /$ polybag, karena campuran tersebut dapat memperbaiki sifat fisik, kimia dan biologi tanah sehingga mendukung pertumbuhan tanaman.

\section{DAFTAR PUSTAKA}

Allorerung, D., 2007. Aren Tanaman Serbaguna. Aren Indonesia. Budidaya dan Pemanfaatan Aren Untuk Bahan Pangan dan Energi.

Gaspersz. II. 1991. Metode Perancangan Percobaan. Amico, Bandung.

Hakim, et al., 1986. Dasar-Dasar Ilmu Tanah. Penerbit Universitas Lampung. Sumatera Selatan.

Maliangkay, R.B. et al., 2002. Pengaruh Pupuk Organik dan Anorganik terhadap Pertumbuahan Bibit Aren. Bul No 26. Pusat Penlitian dan Pengembangan Tanaman Industri, Bogor.

Maliangkay, R.B., 2011. Pengaruh Pemupukan Terhadap Pertumbuhan dan Produksi Nira Aren. Balai Penelitian Tanaman Kelapa dan Palma lain, Manado.

Maliangkay, R.B., 2012. Sumber Benih dan Teknologi Pembibitan Aren. Aren Indonesia. Sumber: http://perkebunan. litbang.deptan. go.id/Aren Indonesia.

Nurmansyah, dan Burhanuddin, 2010. Pengaruh Pemberian Pupuk Kandang dan Kapur Terhadap Pertumbuhan dan Produksi Nilam Pada Tanah Podsolik Merah Kuning. Bul. Littro. 21 (2) : 138144.

Sadari, et al., 2013. Campuran Pupuk Organik Kotoran Ayam dan Tanah Alluvial Pada Bibit Rotan Sega (Calamus caesius Blume) Dipersemaian.

Santoso, B., 2006. Pemberdayaan Lahan Podsolik Merah Kuning dengan Tanaman Rosela (Hibiscus $\begin{array}{lll}\text { sabdariffa } & \text { L.) di Kalimantan }\end{array}$ 
Selatan. Perspektif 5 (1) : 01-12, Malang.

Santoso, A., 2012. Manajemen Kesuburan Tanah Masam Dengan Teknologi Pengapuran.

Sudrajat, D., 2010. Identifikasi Karakter Morfofisiologi Kedelai Adaptif Lahan Masam.Jurnal Penelitian Pertanian Terapan, 10 (2) : 103110.Lampung.

Widodo. 2008. Pupuk Organik dan Pupuk Hayati. Balai Besar Penelitian dan Pengembangan
Sumber Daya Lahan Pertanian, Jawa Barat.

Wijanarko, A. dan Subandi., 2013. Pengaruh Teknik Pemberian Kapur Terhadap Pertumbuhan dan Hasil Kedelai pada Lahan Kering Masam. Penelitian Pertanian Tanaman Pangan, Malang. 32 (3) : 171-178

Yatni, N. dan Syahidah, B, 2008. Penentuan Mutu Cuka Nira Aren (Arenga pinnata) Jurnal Perennial, 5 (1) : 31-35. 